\title{
EFFECT OF SHODHANA (PURIFICATION/PROCESSING) ON POWDER MICROSCOPICAL AND ANALYTICAL PARAMETERS OF GUNJA (ABRUS PRECATORIUS LINN.) SEEDS
}

\author{
SUDIPTA ROY ${ }^{*}$, RABINARAYAN ACHARYA ${ }^{2}$, PREETI PANDYA ${ }^{3}$ \\ 1Ph.D scholar, Department of Dravyaguna, I.P.G.T \& R.A, Gujarat Ayurved University, Jamnagar, ${ }^{2}$ Professor, Department of Dravyaguna, I.P.G.T \\ \& R.A, Gujarat Ayurved University, Jamnagar, ${ }^{3}$ Lab. assistant, Department of Dravyaguna, I.P.G.T \& R.A, Gujarat Ayurved University, Jamnagar \\ Email: sudiptagau@gmail.com \\ Received: 19 May 2016 Revised and Accepted: 09 Sep 2016
}

\section{ABSTRACT}

Objective: Seeds of Gunja (Abrus precatorius Linn.) are being used by the Ayurvedic physicians for the management of different diseases only after proper shodhana (processing) with some specific media like godugdha (cow's milk), kanji (sour gruel) and nimbu swarasa (lemon juice). The impact of shodhana on gunja seed through microscopical and analytical profile have not been studied and reported scientifically yet. Hence, the present study has been designed to evaluate the effect of shodhana on phyto-pharmacognostical characters of Gunja seeds.

Methods: Red variety of Gunja seeds were processed with cow's milk for six hours whereas sour gruel, lemon juice and water (as control) for three hours following the standard procedures for swedana (boiling), recommended by the classical text of Ayurveda. The obtained seeds were investigated for their powder microscopical characters and phytochemical characters like preliminary phytochemical screening (qualitative test) and quantitative estimation for protein following standard protocol.

Results: Organoleptic study shows variations in colour, odour, taste and appearance in all samples (coarse powder) after shodhana. Powder microscopical study highlights some changes like more number of oil globules in godugdha (cow's milk) shodhita and starch grains in kanji (sour gruel) shodhita gunja seeds. Preliminary phytochemical screening reveals the presence of alkaloids, saponin glycoside, flavonoids, reducing sugar, etc. and protein estimation shows the minimization of protein contents in most of the sample after shodhana.

Conclusion: The observed data can be helpful to delineate the impact of shodhana process on gunja seeds.

Keywords: Abrus precatorius, Gunja, Godughdha, Nimbu, Kanji, Protein, Shodhana

(C) 2016 The Authors. Published by Innovare Academic Sciences Pvt Ltd. This is an open access article under the CC BY license (http://creativecommons. org/licenses/by/4. 0/) DOI: http://dx.doi.org/10.22159/ijpps.2016v8i11.12949

\section{INTRODUCTION}

Drugs of herbal origin took lion share in the Ayurveda drug industry. Among the drugs of herbal origin certain plants are known for their toxic effects and are categorized under visha (poisonous) and upavisha (semi-poisonous) drugs and are used either as a single drug or as an ingredient of a compound formulations. The list of poisonous plants has been provided in Schedule E-1 of Drugs and Cosmetics Rule, 1945 [1]. Ayurveda emphasizes on the administration of these poisonous drugs only after through processing technique called as Shodhana (detoxification). The concept of shodhana (purification/processing) in Ayurveda is not only a process of purification or detoxification but also a process which enhances the potency and efficacy of drug [2, 3]. Gunja (Abrus precatorius Linn, Fabaceaea), known as Rosary pea, Jequirity, Indian licorice, a well-known plant of Ayurveda comes under upavisha vargas (sub-poisonous group). Abrus is also renowned as an arrow poison $[2,4]$. It is a wild plant (climber) and grows best in fairly dry regions at low elevation in tropical climates such as India, Srilanka, South china, tropical Africa and West Indies [5].

Gunja has alleged applicability in indigenous system of medicine and is being indicated for the management of various disease conditions like Indralupta (Alopecia), Sotha (edema), Kustha (skin disease), krimi (intestinal worm), etc. after being processed through specific shodhana (purification/processing) [6].

Different phytopharmacological and microscopic evaluation of raw gunja seeds has been already well established [7-9] but the effect of shodhana on powder microscopical characters and some analytical parameters like qualitative and quantitative estimation has not yet been illustrated scientifically. In the present study, an endeavor has been made to evaluate microscopical characters, qualitative tests and quantitative (protein content) estimation of gunja seeds after proper processing through godugdha (cow's milk), nimbu swarasa (lemon juice), kanji (sour gruel) and water as media $[2,10]$.

\section{MATERIALS AND METHODS \\ Collection and selection of plant materials}

The plant Gunja was selected from the surroundings of Jamnagar, Gujarat from their natural habitat and identified by expert plant taxonomist (fig. 1; A). The plant specimen was cross verified with departmental herbarium specimen (Vide. No. Phm/1496/1964) (fig. 1; B). Then the mature seeds (Red variety) were collected by the first author during the month of November-January, 2012. The fully matured dry seeds were first dropped in a beaker containing water for the selection of seeds. The seeds which were floated on the surface of water or those which were damaged, or had faded in colour were discarded. The seeds which settled down at the bottom of the beaker were collected, dried and stored properly for further study.
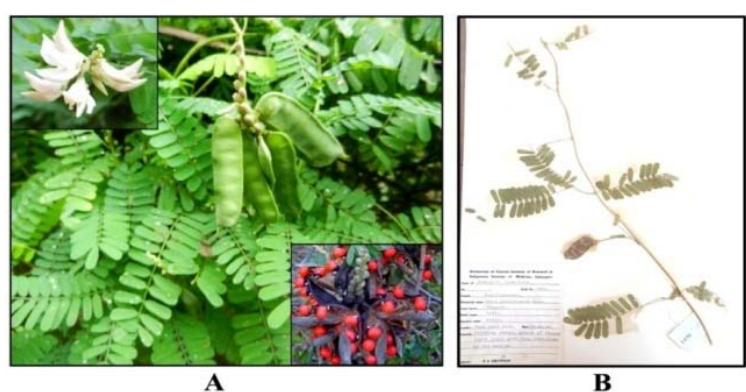

Fig. 1: Morphological characters of raw Gunja, A-Natural habitat of Abrus precatorius Linn; B-Herbarium of Abrus precatorius Linn 


\section{Equipment for Shodhana}

Stainless steel vessel $(20 \mathrm{~cm} \times 30 \mathrm{~cm})$ capacity of which was $7 \mathrm{~L}$ (used as Dolayantra), stainless steel rod (length $28 \mathrm{~cm}$ ), cotton threads $30 \mathrm{~cm}$ in length, measuring mug (capacity of $1 \mathrm{~L}$ ), muslin cloth $(45 \mathrm{~cm} \times 45 \mathrm{~cm})$, digital weighing machine, pyrometer, digital induction cooker (Paasapahce; PSP-3002), stainless steel spatula (length: $30 \mathrm{~cm}$ ) and mechanical mixer grinder (Sumeet domestic mixer catalogue 842-I)

\section{Procedure}

Hundred grams of raw gunja seed (RGS) were kept in a muslin cloth and made into a Pottali, which was immersed in a stainless steel vessel, filled with Godughdha (Cow's milk). Then the assembly was boiled on an induction cooker for $6 \mathrm{~h}$ at $100{ }^{\circ} \mathrm{C}$ throughout the experiment. Totally, seven liters of Godughdha was utilized for one batch throughout the process. After boiling for $6 \mathrm{~h}$, seeds were taken out from pottali and washed with lukewarm water. Then the seeds were allowed to dry in the shade by placing on a blotting paper sheet [2].

After proper drying, the seeds were collected and stored in air tight glass container and labelled as Godughdha shodhita gunja seeds (GSGS).

Same procedure was followed for the Shodhana of Gunja seed with Nimbu swarasa (lemon juice; for $3 \mathrm{~h}$ ) [10], Kanji (Sour gruel; for $3 \mathrm{~h}$ ) [2] and water (obtained from RO plant; for $3 \mathrm{~h}$ ) and the final products were labeled as Nimbu swarasa shodhita gunja seeds (NSGS), kanji shodhita gunja seeds (KSGS) and water shodhita gunja seeds (WSGS).

Two successive experiments in case of all shodhana process (godughdha, nimbu, kanji and water) were carried out taking same quantity of drug and media following same procedures exactly.

\section{Preparation of sample}

Raw and 12 shodhita samples ( 3 batches of each shodhita sample) were individually subjected for powdering through mechanical mixer grinder (passed though mesh no. 60). Then pool samples were prepared by taking equal amount of shodhita samples from each (three) batches of respective sample and mixed them homogeneously. Afterward all samples (RGS, GSGS, NSGS, KSGS and WSGS) were individually stored in glass container and were used for further study.

\section{Preparation of plant extract}

5 g powder of each sample (RGS, GSGS, NSGS, KSGS, and WSGS) was macerated with $100 \mathrm{ml}$ water in a closed flask for twenty-four hours, frequently shaking during six hours and allowed to stand for eighteen hours. After twenty-four hours samples were filtered and water extract was collected. The methanol extract was also prepared following the same procedure. Both extracts were used for Preliminary phytochemical screening [11].

\section{Organoleptic characters}

The colour, odour, taste and appearance of ashodhita/raw (RGS) and all shodhita samples (GSGS, NSGS, KSGS and WSGS) were recorded separately through visual and sensory observation [12].

\section{Powder microscopic evaluation}

Ashodhita/raw (unprocessed) and all shodhita (processed) sample powders $(60 \#)$ were cleaned individually with chloral hydrate to clear the samples. Then the samples were kept on a slide using distilled water and studied under a compound microscope (QUASMA, India) and photographs were taken by using Kodak easy share C140, 8.2 megapixels $3 \mathrm{x}$ optical/5x digital zoom HD camera [13].

\section{Histochemical tests}

Ashodhita/raw (unprocessed) and all shodhita (processed) samples powders were also examined after staining with different suitable reagents i.e. phloroglucinol $(20 \mathrm{mg} / \mathrm{ml}$ of alcohol) along with hydrochloric acid $(6 \mathrm{~N})$, Sudan III and Iodine solution (2g iodine and $3 \mathrm{~g}$ potassium iodide in $100 \mathrm{ml}$ water) $[10,11]$ for the assessment of lignified cellular content, under compound microscope (QUASMA, India) and photographs were taken by using Kodak easy share C140, 8.2 megapixels $3 \mathrm{x}$ optical/5x digital zoom HD camera.

\section{Preliminary phytochemical screening}

The extracts of raw (unprocessed) and all shodhita (processed) samples (water and methanol extract) were subjected to phytochemical screening for the assessment of various plant constituents such as alkaloid, carbohydrate, protein, steroid, terpenoid, glycoside, flavonoid, tannin following standard procedures [14].

\section{Quantitative estimation of protein content}

Quantitative estimation of crude protein was evaluated by the Kjeldahl method for nitrogen [15]

\section{RESULTS}

\author{
Macroscopic characters of full seed before shodhana (fig. 2; A \\ and $B$ )
}

Shape: -ovoid to spherical in shape

Size: -Seed attains a length of $0.9 \mathrm{~cm}$ and $0.5 \mathrm{~cm}$ in diameter.

Surface: -Glossy and shining.

Colour:-Bright red scarlet with black color near the hilum.

Odour: -Nil.
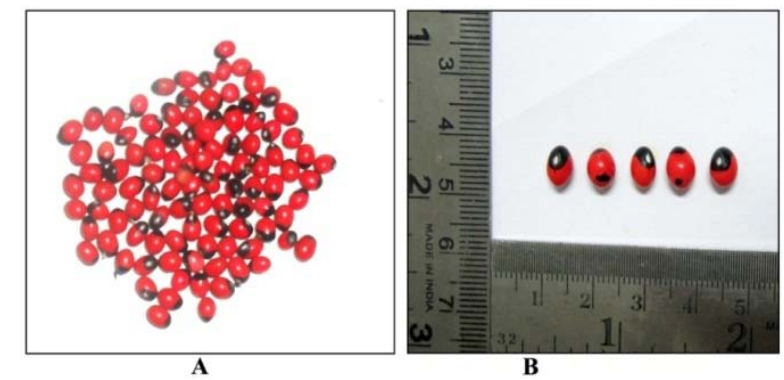

Fig. 2: Organoleptic characters of raw gunja seeds, A-Scarlet red Gunja seeds; B-Measurements of Gunja seeds

Organoleptic characters of raw and shodhita sample powders

Detail organoleptic characters like colour, odour, taste and appearance of raw gunja seed (RGS) powder and all shodhita gunja seed (GSGS, NSGS, KSGS and WSGS) powder has been depicted in table 1(fig. 3; A-E).

Table 1: Observed organoleptic characters of raw and all shodhita Gunja seed samples

\begin{tabular}{|c|c|c|c|c|}
\hline Sample & Colour & Odour & Taste & Appearance \\
\hline RGS & $\begin{array}{l}\text { Reddish } \\
\text { cream }\end{array}$ & Typical & Bitter & $\begin{array}{l}\text { Smooth, } \\
\text { shiny and } \\
\text { hard }\end{array}$ \\
\hline GSGS & $\begin{array}{l}\text { Brownish } \\
\text { after } \\
\text { drying }\end{array}$ & $\begin{array}{l}\text { Characteristic } \\
\text { of milk }\end{array}$ & $\begin{array}{l}\text { Sweetish } \\
\text { bitter }\end{array}$ & $\begin{array}{l}\text { Dull and } \\
\text { brittle }\end{array}$ \\
\hline NSGS & $\begin{array}{l}\text { Creamish } \\
\text { yellow }\end{array}$ & $\begin{array}{l}\text { Characteristic } \\
\text { of } \\
\text { nimbuswarasa }\end{array}$ & $\begin{array}{l}\text { Sour } \\
\text { with } \\
\text { bitter }\end{array}$ & $\begin{array}{l}\text { Dull and } \\
\text { brittle }\end{array}$ \\
\hline KSGS & $\begin{array}{l}\text { Yellowish } \\
\text { brown }\end{array}$ & $\begin{array}{l}\text { Characteristic } \\
\text { of Kanji }\end{array}$ & $\begin{array}{l}\text { Sour and } \\
\text { bitter }\end{array}$ & $\begin{array}{l}\text { Dull and } \\
\text { brittle }\end{array}$ \\
\hline WSGS & Ash color & Typical & Bitter & $\begin{array}{l}\text { Dull and } \\
\text { brittle }\end{array}$ \\
\hline
\end{tabular}

RGS-Raw gunja seeds; GSGS-Godughdha shodhita gunja seed; NSGSNimbu swarasa shodhita gunja seeds; KSGS-Kanji shodhita gunja seeds; WSGS-Water shodhita gunja seeds. 

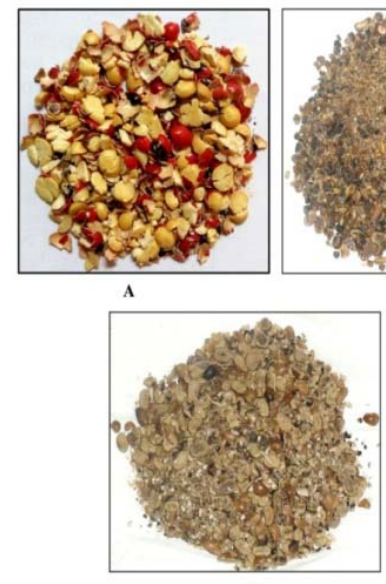

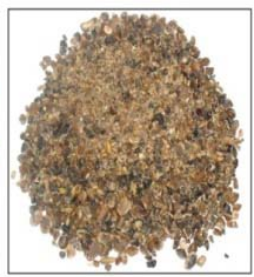

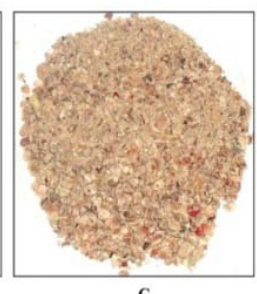

Fig. 3: Samples of Gunja seed before and after Shodhana, ACoarse powder of raw Gunja seeds; B-Godugdha shodhita Gunja seeds; C-Nimbu swarasa shodhita Gunja seeds; D-Kanji shodhita Gunja seeds; E-Water shodhita Gunja seeds

\section{Powder microscopical study of raw and shodhita samples}

\section{Raw gunja seed}

Powder microscopy of raw gunja seeds shows the diagnostic characters like fragments of transversely cut palisade like cells having radially thickened walls and narrow lumen with pinkish and violet colored pigments, wavy compact spool-shaped cells, fragment of thin walled parenchymatous cells, fragments of endosperm in surface view, fragments of pitted thickened tracheidal bar from hilum region, fragments of non-lignified fibers and fragment of fragment of cotyledon cells embedded with yellowish brown content and aleurone grain (fig. 4; A-D).

\section{Godugdha shodhita gunja seed}

Powder microscopy of Godugdha shodhita gunja seeds shows the diagnostic characters like fragment of palisade like cells of testa having radially thickened walls and narrow lumen with violet colored pigments, spool-shaped cells of sub-epidermis, fragments of endosperm in surface view, fragment of pitted thickened tracheidal bar from hilum region, fragment of fibres, fragment of cotyledon cells embedded with yellow content and aleurone grains (fig. 4; E-H).

\section{Nimbu swarasa shodhita gunja seed}

Powder microscopy of Nimbu swarasa shodhita gunja seeds shows the diagnostic characters like fragment of palisade-like cells of testa having radially thickened walls, spool shaped cells, fragment of pitted tracheidal bar from hilum region, fragment of annular vessels, fragment of fiber, starch grain, fragment of cotyledon cells embedded with yellowish brown content and aleurone grains (fig. 4; I-L).

\section{Kanji shodhita gunja seed}

Powder microscopy of Kanji shodhita gunja seeds shows the diagnostic characters like transversely cut fragment of palisade-like cells of testa having radially thickened walls and narrow lumen, spool-shaped cells, endosperm cells in surface view, fragment of pitted tracheids bar from hilum region, fragment of spiral vessels, fragment of fiber, ample amount starch grain (both compound and simple), fragment of parenchyma cell embedded with starch grain, fragment of cotyledon cells embedded with brownish yellow content and aleurone grains (fig. 5; A-D).

\section{Water shodhita gunja seed}

Powder microscopy of Water shodhita gunja seeds shows the diagnostic characters like fragment of swollen-based palisade-like cells of testa having radially thickened walls and narrow lumen, spool-shaped cells, fragment of endosperm cells in surface view, fragment of pitted tracheidal bar from hilum region, fragment of fiber, fragment of cotyledon cells embedded with yellow content and aleurone grains (fig. 5; E-I).

\section{Histochemical tests}

The result of histochemical tests shows that Lignified cells of tracheidal bar and vessels are present in ashodhita and shodhita samples. Results also highlight that oil globules are absent in kanji shodhita and water shodhita gunja seeds whereas starch is present only in nimbu swarasa shodhita and kanji shodhita samples (table 2).

\section{Preliminary phytochemical screening of raw and shodhita sample extracts}

Detail results of phytochemical screening has been mentioned in table 3. The study shows the presence of alkaloids, saponin glycoside, flavonoids and reducing sugar in all five (RGS, GSGS, NSGS, KSGS and WSGS) samples. The result also shows that amino acid is present only in two samples i.e. RGS and NSGS and starch is present in RGS and KSGS whereas protein is absent or may be present in an undetectable amount in all shodhita sample.

Table 2: Results of histochemical tests of raw and all shodhita samples

\begin{tabular}{|c|c|c|c|c|}
\hline Sample & Reagents & Observation & Characteristics & Results \\
\hline \multirow[t]{4}{*}{ Raw gunja seeds(RGS) } & Phloroglucinol+conc. HCL & Reddish pink & Lignified cells of tracheidal bar and vessels & + \\
\hline & Iodine & Blue & Starch & - \\
\hline & & Yellow & Aleurone grain & + \\
\hline & Sudan III & Red & Oil globules & + \\
\hline \multirow[t]{4}{*}{ Godughdha shodhita gunja seeds(GSGS) } & Phloroglucinol+conc. HCL & Reddish pink & Lignified cells of tracheidal bar and vessels & + \\
\hline & Iodine & Blue & Starch & - \\
\hline & & Yellow & Aleurone grain & + \\
\hline & Sudan III & Red & Oil globules & + \\
\hline \multirow{4}{*}{$\begin{array}{l}\text { Nimbu swarasa shodhita gunja } \\
\text { seeds(NSGS) }\end{array}$} & Phloroglucinol+conc. HCL & Reddish pink & Lignified cells of tracheidal bar and vessels & + \\
\hline & Iodine & Blue & Starch & + \\
\hline & & Yellow & Aleurone grain & + \\
\hline & Sudan III & Red & Oil globules & + \\
\hline \multirow[t]{4}{*}{ Kanji shodhita gunja seeds(KSGS) } & Phloroglucinol+conc. HCL & Reddish pink & Lignified cells of tracheidal bar and vessels & + \\
\hline & Iodine & Blue & Starch & + \\
\hline & & Yellow & Aleurone grain & + \\
\hline & Sudan III & Red & Oil globules & - \\
\hline \multirow[t]{4}{*}{ Water shodhita gunja seeds(WSGS) } & Phloroglucinol+conc. HCL & Reddish pink & Lignified cells of tracheidal bar and vessels & + \\
\hline & Iodine & Blue & Starch & - \\
\hline & & Yellow & Aleurone grain & + \\
\hline & Sudan III & Red & Oil globule & - \\
\hline
\end{tabular}

'+'-Present, '-'-Absent 


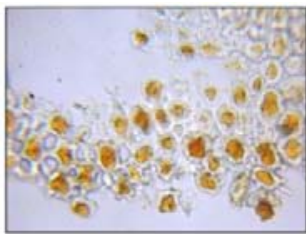

A
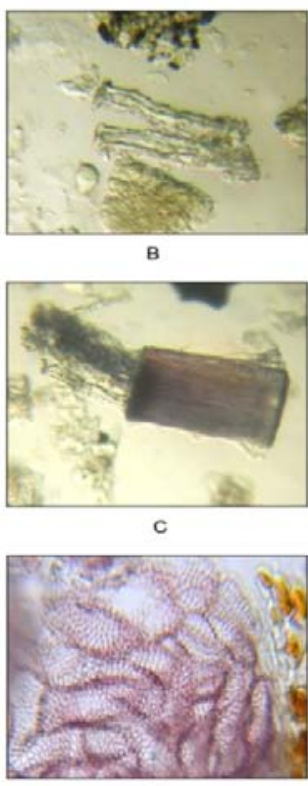

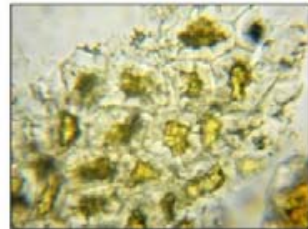

$\mathrm{E}$

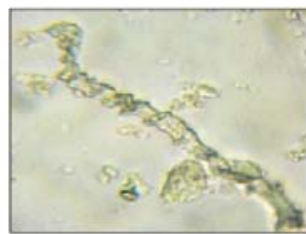

F
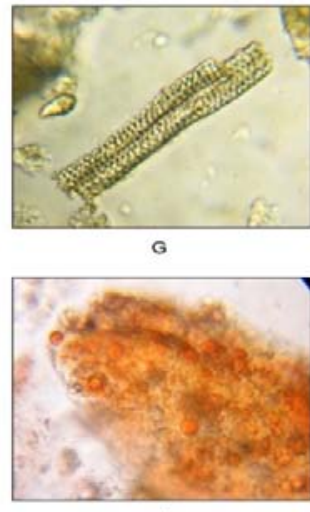
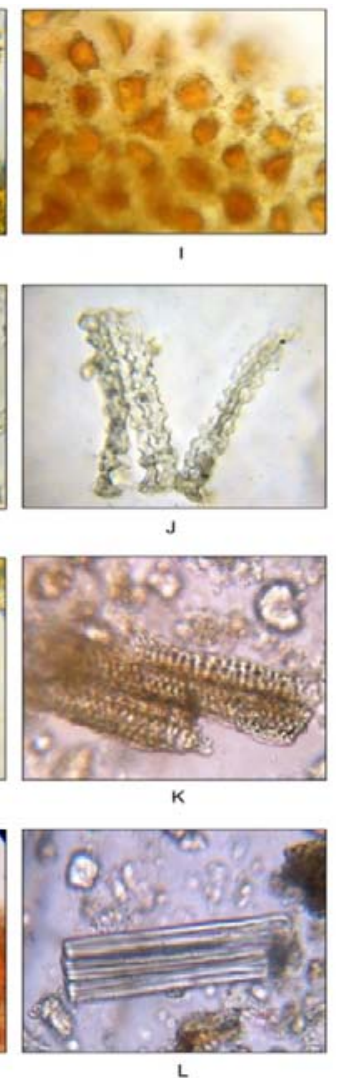

Fig. 4: Powder microscopical characters of raw, GSGS and NSGS, A-Cotyledon cell of raw seed; B-Fragment of spool-shaped parenchyma cells of raw; C-Fragments of palisade parenchyma with spool-shaped parenchyma of raw; D-Pitted tracheids stained with

Phloroglucinol+Hcl of raw; E-Fragment of cotyledon cell of GSGS; F-spool shaped parenchyma of GSGS; G-Pitted vessels of GSGS; H-Oil globules stained with sudan III of GSGS; I-cotyledon cell of NSGS; J-spool shaped parenchyma of NSGS; K-Pitted vessels of NSGS; L-

Fragment of palisade like cell of NSGS, [GSGS-Godugdha shodhita gunja seed; NSGS-Nimbu swarasa shodhita gunja seed

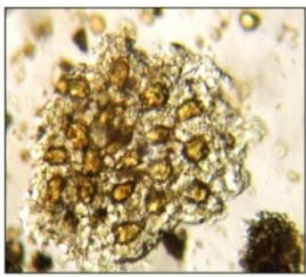

A

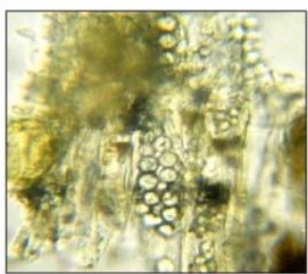

D

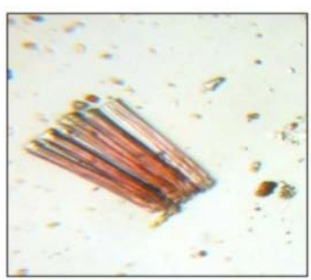

G

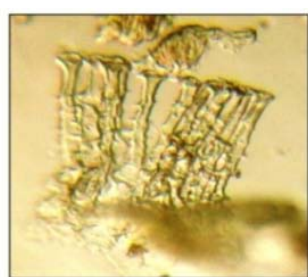

B

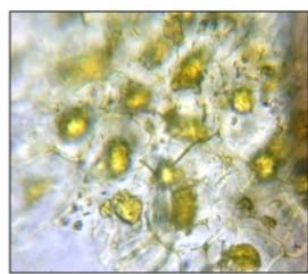

$\mathrm{E}$

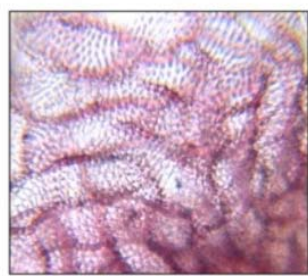

$\mathrm{H}$

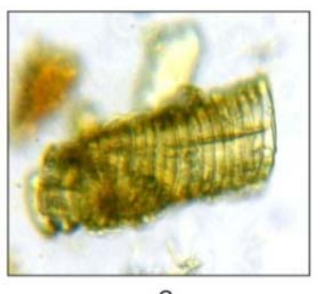

c

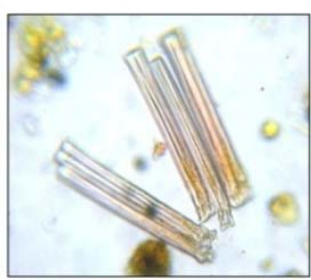

$\mathrm{F}$

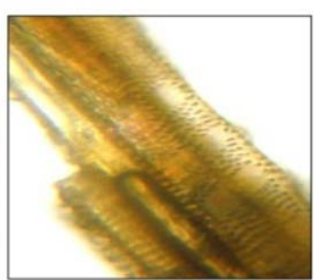

।

Fig. 5: Powder microscopical characters of KSGS and WSGS, A-Cotyledon cell of KSGS; B-Fragment of spool-shaped parenchyma cells of KSGS; C-Fragments of spiral vessel of KSGS; D-Parenchyma cell embedded with starch grain of KSGS; E-Fragment of cotyledon cell of WSGS; F-fragment of swollen-based palisade like cells of WSGS; G-Fragment of palisade like cell of WSGS; H-Pitted tracheids, stained with Phloroglucinol+Hcl of WSGS; I-Fragment of pitted vessel of WSGS; [KSGS-Kanji shodhita gunja seed; WSGS-Water shodhita gunja seed 
Table 3: Results of preliminary phytochemical screening of raw and all shodhita samples

\begin{tabular}{|c|c|c|c|c|c|c|c|}
\hline Test for & Applied test & Standard observation & RGS & GSGS & NSGS & KSGS & WSGS \\
\hline \multirow[t]{2}{*}{ Tannin and phenolic acid } & $\mathrm{Fecl}_{3} \mathrm{Sol}$ & Greenish & + & - & + & + & + \\
\hline & Ammonia test & Yellow & + & - & + & + & + \\
\hline Saponin glycoside & Foam test & Froth/foam & + & + & + & + & + \\
\hline Reducing sugar & Fehling's test & Brick red ppt. & + & + & + & + & + \\
\hline \multirow[t]{2}{*}{ Glycoside } & Legal's test & Pink or red. & + & - & + & + & - \\
\hline & Borntrager's test & pink or red layer & + & - & - & + & + \\
\hline \multirow[t]{2}{*}{ Protein } & Biuret test & violet/pink & + & - & - & - & - \\
\hline & Precipitation test & white colloidal ppt. & + & - & - & - & - \\
\hline Amino acid & Ninhydrin test & Purple/blue & + & - & + & - & - \\
\hline Steroids & Salkowski test & Red/brown & + & - & + & + & + \\
\hline Mucilage & Swelling test & Swelling & + & + & + & + & + \\
\hline Fats and oil & Filter paper test & Stained with oil & - & - & - & - & - \\
\hline \multirow[t]{3}{*}{ Flavonoids } & Shinoda test. & Pink colour & + & + & - & + & - \\
\hline & Lead acetate test. & White ppt. & + & - & + & + & - \\
\hline & Alkaline reagent test & Yellow to decolourisation & + & - & + & + & - \\
\hline \multirow[t]{2}{*}{ Alkaloids } & Dragendorff's reagent. & Orange ppt. & + & + & + & + & + \\
\hline & Wagner's reagent & Reddish brown ppt. & + & - & - & + & - \\
\hline Starch & Iodine test & Blue colour & + & - & - & + & - \\
\hline
\end{tabular}

RGS-Raw gunja seeds; GSGS-Godughdha shodhita gunja seed; NSGS-Nimbu swarasa shodhita gunja seeds; KSGS-Kanji shodhita gunja seeds; WSGSWater shodhita gunja seeds. '+'-Present; '-'-Absent

Table 4: Total protein content of raw and all shodhita samples

\begin{tabular}{lllllll}
\hline S. No. & Method & RGS & GSGS & NSGS & KSGS & $14.36 \%$ \\
\hline 1 & GAFTA & $17.33 \%$ & $14.90 \%$ & $17.78 \%$ & $14.04 \%$ & \\
\hline
\end{tabular}

RGS-Raw gunja seeds; GSGS-Godughdha shodhita gunja seed; NSGS-Nimbu swarasa shodhita gunja seeds; KSGS-Kanji shodhita gunja seeds; WSGSWater shodhita gunja seeds

\section{Total protein content of raw and shodhita sample powders}

Detail results of total protein content of ashodhita and all shodhita samples has been given in table 4 . The result shows that protein content has been decreased in most of the sample after shodhana.

\section{DISCUSSION}

Shodhana (purification/processing) is a process by which blemishes are separated from the substance by means of different pharmaceutical processes like swedana (boiling), bhavana (levigation), achusana (absorption), etc. [16]. In this study shodhana of gunja seeds were done through swedana process, mentioned in classics and traditional texts $[2,10]$. Principles of Swedana methods is similar to the common stages of extraction process such as a drug in dry state is porous due to the shrinkage, and the pores contain air that must be displaced as the solvent enters into the pores and penetrate into the cells. Cell walls consist basically cellulose molecules in the form of ultra-microscopic, spirally shaped fibrils running parallel to the axis of the cell. When the dry drug is moistened these cellulose molecules take up a liquid film and resulting the swelling of the tissues and solvent has penetrated into the cells, solution of the soluble constituents takes place within the cells followed by escape of dissolved material into the solvent through the solvent boundary layer by the process of diffusion and finally separation of the soluble constituents into solvent from the drug occurs. The rate of extraction depends mainly on the temperature gradient and concentration gradient across the cell membrane. The rate of extraction and solubility is increased by elevation of temperature. Rising temperature increases the concentration gradient across the cell membrane thereby increasing mass transfer of active principles from solid material to the solvent [17].

In the present study, generated data reflects the effect of shodhana on the organoleptic, microscopical, qualitative and quantitative study.

Organoleptic parameter shows that reddish (external) cream (internal) colour ashodhita/raw seed powder turns into brownish, creamish yellow, yellowish brown and ash colour in case of godughdha shodhita, nimbuswarasa shodhita, kanji shodhita and water shodhita respectively, might be due to the removal of colour containing material from the seed/seed coat into media after processing through different media [17]. Odour and taste of gunja seeds after shodhana are also changed as per the media changes indicates the incorporation of media into the seed.

Powder microscopical character shows some common characters like fragment of palisade like cell, spool cell, endosperm in surface view, fragment of fiber, pitted traceidal bar etc. whereas some specific characters like presence of ample amount of oil globule in godughdha shodhita sample, huge amount of starch grain in kanji shodhita sample, swollen base palisade like cell in water shodhita sample in comparison to ashodhita/raw sample, highlights the effect of different media on gunja seed.

Preliminary phytochemical screening reveals the absence/ untraceable of protein in all shodhita sample in comparison to raw sample. It may be due the removal or denaturation of chief toxic protein (abrin) from gunja seed after processing or heating during shodhana [4]. Quantitative estimation of total protein also highlights the decrease of protein content after shodhana in most of the samples, serving the same reason of preliminary screening. In the case of nimbu swarasa shodhita sample result shows both the presence of amino acid in preliminary screening and increase the amount of total protein content in compare of other shodhita samples may be because of the addition of some protein moiety from nimbu swarasa to gunja seed.

\section{CONCLUSION}

The findings of the present study fully justify the claims of ancient ayurvedic classics that shodhana effect on different parameters such as macroscopic and microscopic characters, quality and quantity of different plant metabolites.

\section{ACKNOWLEDGEMENT}

Authors express their sincere thanks to Dr. V. J. Shukla (Head, pharmaceutical chemistry Laboratory, I. P. G. T andR. A) and Dr. Harisha C. R (Head, Pharmacognosy laboratory I. P. G. T andR. A) for providing necessary permission to carry out analytical and pharmacognostical work in their laboratories. 


\section{CONFLICTS OF INTERESTS}

Declared none

\section{REFERENCES}

1. Acharya RN. Shodhana: an Ayurvedic detoxification technique and its impact on certain medicinal plants. In: Conservation, Cultivation, and Exploration of Therapeutic potential of Medicinal plants. New Delhi: CCRAS, Dept. of AYUSH, Ministry of Health and Family health welfare, Govt. of India; 2014. p. 427-50.

2. Sharma S. Editor. Rasatarangini of Kashinathshastrina. Delhi: Motilal Banarasidas; 2009. p. 727-30.

3. Mitra S, Shukla VJ, Acharya RN. The role of castor oil in processing (Shodhana) of Kupeelu (Strychnos nuxvomica Linn.) seeds an approach of traditional Ayurveda. Int J Ayurvedic Med 2011;2:62-71.

4. Parikh CK. Parikh's test book of medical jurisprudence forensic medicine and toxicology. 6h Ed. New Delhi: CBS Publishers and Distributors; 2007. p. 9.31-11.16.

5. Roy S, Acharya RN. A review on therapeutic utilities and purificatory procedure of Gunja (Abrus precatorius Linn) as described in Ayurveda. Res Rev: J Agric Sci Technol 2013;2:1-11.

6. Gupta AK, Tandon N. editor. Review on Indian medicinal plants. Vol. 1. New Delhi: Indian council of medical research; 2004. p. 18-20.

7. Chauhan MG, Pillai APG. Microscopic profile of drugs used in Indian systems of medicine. Seed drugs. Vol. 3. Part-I. Jamnagar: P. G. T-S. F. C. cell, I. P. G. T and R. A, Gujarat Ayurved University; 2011. p. 1-2.
8. Tabasum S, Khare S, Jain K. Spectrophotometric quantification of total phenolic, flavonoid, and alkaloid contents of abrus precatorius l. Seeds. Asian J Pharm Clin Res 2016;9:371-4.

9. Suralkar A, Gund AK. Gastroprotective effect of Abrus precatorius on ethanol-induced and aspirin+pylorus ligation-induced peptic ulcer in rats. Asian J Pharm Clin Res 2014;7:57-62.

10. Garga VD, Trivedi KP, Vanausadhi D, Vishesanka. Khanda-2. Aligarh: Shri Jwala Ayurveda Bhavan; 2004. p. 340-4.

11. Anonymous. The Ayurvedic Pharmacopoeia of India. Part-II. Vol. II. First edition. New Delhi: Government of India, Ministry of Health and Family Welfare, Department of AYUSH; 2008. p. 159-61.

12. Wallis TE. Textbook of Pharmacognosy. Fifth ed. New Delhi: CBS Publishers and Distributors; 2002. p. 578-81.

13. Khandelwal KR. Practical pharmacognosy. Nineteenth ed. Pune: Nirali Prakashan; 2008. p. 146-48, 162-5.

14. Khandelwal KR. Practical pharmacognosy. Nineteenth ed. Pune: Nirali Prakashan; 2008. p. 149-56.

15. http://www.brooklyn.cuny.edu/bc/ahp/SDKC/Chem/SD_Kjeld ahlMethod.html. [Last accessed on 15 Apr 2016].

16. Sharma S. Editor. Rasatarangini of Kashinathshastrina. Delhi: Motilal Banarasidas; 2009. p. 22.

17. Carter SJ. Editor. Tutorial pharmacy of Cooper and Gunn's. Sixth edition. New Delhi: CBS publishers and distributors; 1999. p. 252-60.

\section{How to cite this article}

- Sudipta Roy, Rabinarayan Acharya, Preeti Pandya. Effect of shodhana (purification/processing) on powder microscopical and analytical parameters of gunja (Abrus precatorius Linn.) seeds. Int J Pharm Pharm Sci 2016;8(11):80-85. 